\title{
Article \\ Effect of Climate Change on Staple Food Production: Empirical Evidence from a Structural Ricardian Analysis
}

\author{
Yir-Hueih Luh * (D) and Yun-Cih Chang
}

Department of Agricultural Economics, National Taiwan University, Taipei 10617, Taiwan; f08627010@ntu.edu.tw * Correspondence: yirhueihluh@ntu.edu.tw; Tel.: +886-2-33662651

Citation: Luh, Y.-H.; Chang, Y.-C. Effect of Climate Change on Staple Food Production: Empirical Evidence from a Structural Ricardian Analysis. Agronomy 2021, 11, 369. https:// doi.org/10.3390/agronomy11020369

Academic Editor: Riccardo Testa

Received: 28 December 2020

Accepted: 12 February 2021

Published: 19 February 2021

Publisher's Note: MDPI stays neutral with regard to jurisdictional claims in published maps and institutional affiliations.

Copyright: (c) 2021 by the authors. Licensee MDPI, Basel, Switzerland. This article is an open access article distributed under the terms and conditions of the Creative Commons Attribution (CC BY) license (https:// creativecommons.org/licenses/by/ $4.0 /)$.

\begin{abstract}
The structural Ricardian model has been used to examine the links between climate variables and staple food production in the literature. However, empirical extensions considering the cluster-correlated effects of climate change have been limited. This study aims to bridge this knowledge gap by extending the structural Ricardian model to accommodate for spatial clustering of the climate variables while examining their effects on staple food production. Based on nationally representative farm household data in Taiwan, the present study investigates the effect of climate conditions on both crop choice and the subsequent production of the three most important staple foods. The results suggest that seasonal temperature/precipitation variations are the major determinants of staple food production after controlling for farm households' socio-economic characteristics. The impacts of seasonal climate variations are found to be location-dependent, which also vary significantly across the staple food commodities. Climate change impact assessment under four Representative Concentration Pathways (RCPs) scenarios indicates the detrimental effect of climate change on rice production during 2021-2100. Under RCP6.0, the adverse effect of climate change on rice production will reach the high of approximately $\$ 2900$ in the last two decades of the century. There is a gradual increase in terms of the size of negative impact on vegetable production under RCP2.6 and RCP4.5. Under RCP6.0 and RCP8.5, the effects of climate change on vegetable production switch in signs during the entire time span. The impact of climate change on fruits is different from the other two staple foods. The simulated results suggest that, except for RCP8.5, the positive impact of climate change on the production of fruits will be around $\$ 210-\$ 320$ in 2021-2040; the effect will then increase to $\$ 640-\$ 870$ before the end of the century.
\end{abstract}

Keywords: climate change impact assessment; crop choice; staple food production; structural Ricardian model; clustered-data analysis

\section{Introduction}

The effect of climate change on crop production or productivity has been subject to substantial scrutiny in the literature since the first rigorous assessment in the 1975 Climate Impact Assessment Project [1,2]. Although most early studies of climate change assessment focused on the US and Europe [2], there is emerging interests in assessing the impact of climate change on agriculture for developing countries, for example, [3-9], since the tropical and subtropical regions are projected to be affected to the greatest extent [10-12]. Through an examination of the impact of climate change from a global perspective, some authors [13-15] suggested the impact of climate change varies with the latitude of the targeted regions. It was noted that climate impact assessment based on a global scale suffered under the exploration of spatially specific nature of the data and aggregations that smoothed out spatial variations within a region or country [14]. In light of the lack of empirical evidence from a country-specific study, there were a few studies, for example, [16-28], that assessed the impacts of climate change based on a micro-level (farm or farm household) analysis. 
Drawn from nationally representative farm household data in Taiwan, the present study aims at examining the effect of climate variables, including temperature and precipitation, on the production of the three most important staple foods: rice, vegetables and fruits. The use of farm household data in Taiwan for climate change impact assessment is relevant, since more than $98 \%$ of the 721,224 farm households who engaged in agriculture production in Taiwan are growers of crops including rice, vegetables, fruits, specialty crops, grains and other crops [29]. Examination of the effect of climate change on food production in Taiwan can provide solid evidence and a significant complement to the existing body of knowledge.

The contribution of the present study is three-fold. First, most of the country- or region-specific studies in Asia are targeted at South Asian countries. Insufficient evidence of the effect of climate change on Northeast Asian agriculture accentuates the need to explore the impacts of climate change in the region. Second, one common characteristic of most northeast Asian countries is their structure, with the majority of farms being small in scale [30]. Taking Taiwan as an example, the average size of the farmland is approximately 1.02 hectares according to the most recent statistics. Empirical evidence supporting the climate effect on Taiwan's staple food production provides a significant complement to the scant literature on the losses or gains of smallholder farms in their process of adaptation to climate change. Third, Taiwan is characterized by clear spatial and seasonal variations in temperature and rainfall. There are two distinct climatic characters on the island: "the tropical monsoon climate in the south and subtropical monsoon climate in the north" [31]. This study, therefore, can advance our understanding of how the impact of climate change varies with seasonal or spatial variability within a country.

The major research problem this study attempts to address is: What are the effects of climate change on farm households' production of staple foods of various kinds? To this end, we base our analysis on the structural Ricardian model [32]. The Ricardian or structural Ricardian models have been used to examine the effect of climate change, addressing the production-related effects of current climatic conditions and a long-term projection or simulation of the effect of climate change $[27,28,33-42]$. However, empirical extensions to considering the cluster-correlated effect of climate on food production have been limited. This study aims to bridge this knowledge gap by extending the structural Ricardian model to accommodate for spatial clustering of the climate variables while examining their effects on staple food production.

The remainder of this paper is as follows. Section 2 presents the spatial variations in climate variables and the distribution of the three staple foods in Taiwan. Section 3 delineates the 2015 Census of Agriculture, Forestry, Fishery and Animal Husbandry data (in short, 2015 Agriculture Census data) and the structural Ricardian model. Following Section 3 are the results and discussion. The final section summarizes the major findings and possible future extensions of the present research.

\section{Spatial Distribution of Staple Foods and Climatic Variations}

The spatial distribution of the three staple foods are different (Figure 1). Rice is more concentrated in the coastal area of central and central-south counties. Among the top three counties, the first two are located in central Taiwan while the third is located in the south. The largest county in the central area, Nantou county, is an inland county which takes a relatively small share of total rice production in Taiwan. Although vegetables are also more concentrated in central Taiwan, the counties in the top club tend to be located more in the south when compared to the top club of rice. Among the top three counties producing vegetables, one is in the central area while the other two are in the south. The spatial distribution of fruits is mainly concentrated in southern Taiwan. The top three counties producing fruits are all in the south. A comparison of the spatial distribution of rice, vegetables and fruits indicates a shift from north-central to central and south. 

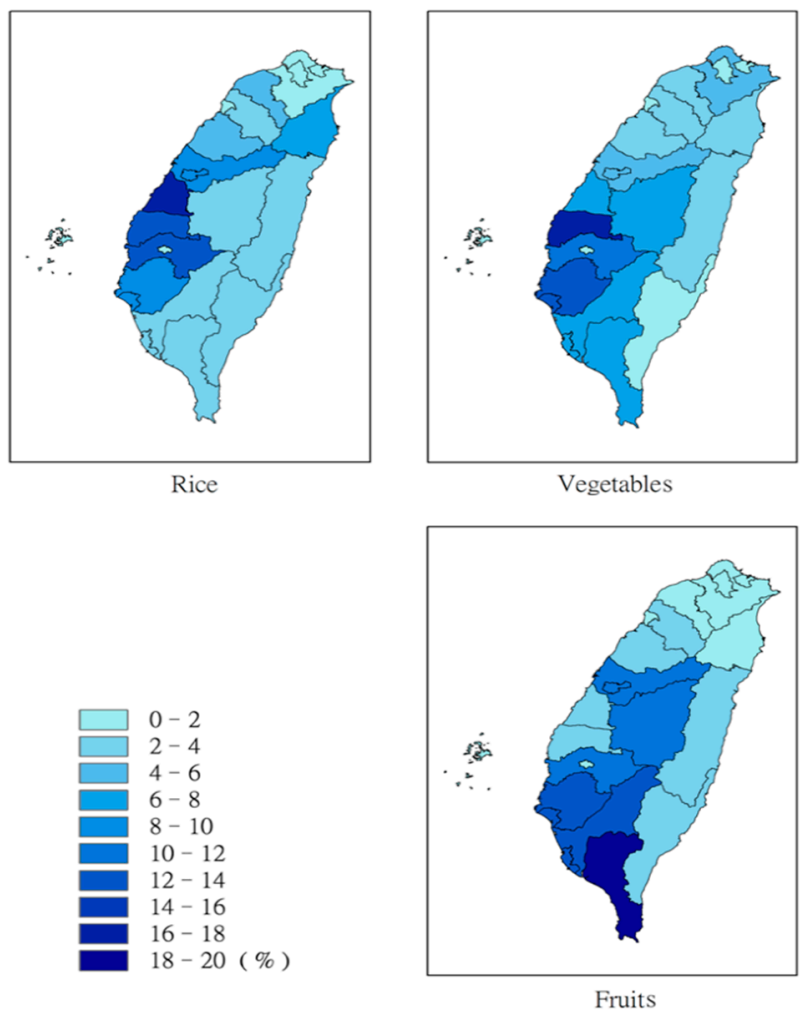

Figure 1. Spatial distribution of rice, vegetables and fruits.

The temperature in Taiwan has been rising by about $1.3^{\circ} \mathrm{C}$ in the past 100 years, which is projected to rise by $1.3-1.8^{\circ} \mathrm{C}$ under the representative concentration pathway (RCP) 4.5 scenario, and may reach the high of a $3.0-3.6^{\circ} \mathrm{C}$ surge at the end of this century under an RCP 8.5 scenario [43]. On average, there is a mild spatial difference in temperature; the annual temperature in southern Taiwan is about 24 and $22{ }^{\circ} \mathrm{C}$ in the north [31]. In contrast to the mild spatial variations in temperature, the variations in precipitation are more obvious (Figure 2).

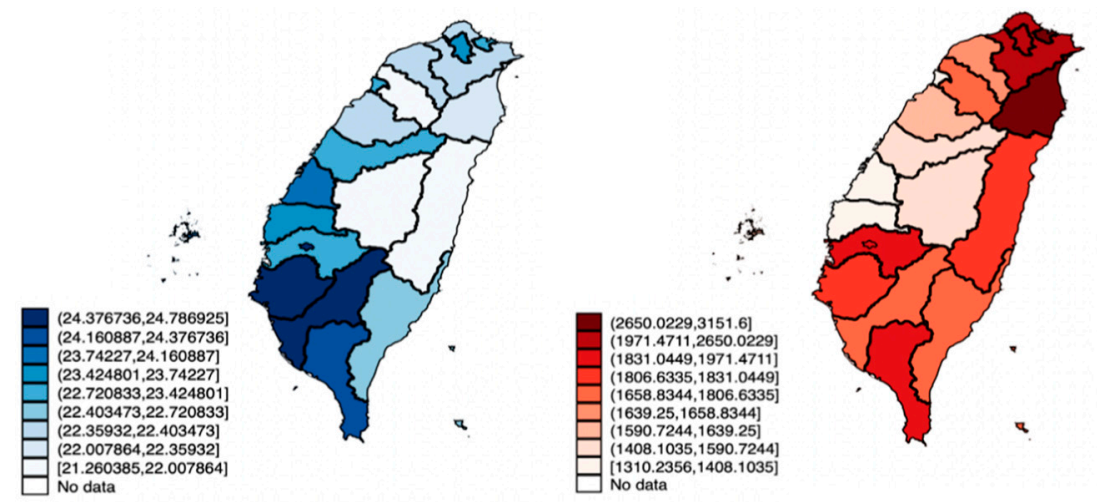

Figure 2. Spatial climatic variations (left panel: temperature; right panel: rainfall).

Taiwan lies between the Eurasian and the Pacific, and thus the seasonal variations in rainfall are mainly affected by the Siberian High and Pacific Subtropical high and its accompanying circulation and weather system [44]. The wet season in Taiwan starts from May to October, which is followed by the dry season, until 1 April the following year. During the dry season, the rainfall in central and southern Taiwan decreases rapidly from October, whereas there is still considerable rainfall in the north and east of the windward side [45]. 


\section{Materials and Methods}

\subsection{Data and Descriptive Statistics}

The data used in the present research are taken from the $1 \%$ sampling data from the 2015 Agriculture Census data, which was recently released by the Executive Yuen in Taiwan. According to the description of the Directorate General of Budget, Accounting and Statistics [29], the 1\% sampling data of the 2015 Agriculture Census is randomly sampled from a total of 845,241 farm households, resulting in 6950 farm households in total. After deleting the farm households whose major farm operation is livestock or who did not engage in farming for land use, the data of farm households number 5315. We focus on the farm households producing the three staple foods, rice, vegetables and fruits, which comprise around $85 \%$ of the farm households producing mainly crops. According to the codebook of 2015 Agriculture Census Survey, the fruits and vegetables included in the two food groups are listed in Appendix A (Table A1). The final dataset contains a sample size of 4487 farm households. Descriptions and descriptive statistics of the dependent and explanatory variables are listed in Table 1 . Note that most of the farm households produce more than one crop; classification of the single staple food commodity is defined in terms of the crop taking the largest share in total production value.

Table 1. Variable definition and descriptive statistics.

\begin{tabular}{|c|c|c|c|}
\hline Variable & Definition & Mean & Std Dev \\
\hline \multicolumn{4}{|l|}{ Outcome } \\
\hline Production Value & $\begin{array}{l}\text { Production value (National Taiwan Dollar, NTD, } \\
\text { per unit farmland) of major crop }\end{array}$ & 3608.729 & 4836.03 \\
\hline \multicolumn{4}{|l|}{ Crop choice } \\
\hline Rice & Crop (rice) & 0.459 & 0.50 \\
\hline Vegetables & Crop (vegetable) & 0.213 & 0.41 \\
\hline Fruits & Crop (fruit) & 0.329 & 0.47 \\
\hline \multicolumn{4}{|l|}{$\begin{array}{l}\text { Principal operator's } \\
\text { characteristics }\end{array}$} \\
\hline Male & Gender of the principal operator & 0.806 & 0.40 \\
\hline Age1 & Age (45-54 years old) & 0.050 & 0.22 \\
\hline Age2 & Age (55-64 years old) & 0.198 & 0.40 \\
\hline Age3 & Age (55-64 years old) & 0.299 & 0.46 \\
\hline Age4 & Age (65-75 years old) & 0.250 & 0.43 \\
\hline Age5 & Age (more than 75 years old) & 0.204 & 0.40 \\
\hline Elementary & Education (elementary school and below) & 0.445 & 0.50 \\
\hline Junior high & Education (junior high school) & 0.236 & 0.42 \\
\hline Senior high & Education (senior high school) & 0.245 & 0.43 \\
\hline College & Education (college and above) & 0.073 & 0.26 \\
\hline Exp1 & Farm experience (less than 5 years) & 0.090 & 0.29 \\
\hline Exp2 & Farm experience ( 5 to less than 10 years) & 0.118 & 0.32 \\
\hline Exp3 & Farm experience ( 10 to less than 20 years) & 0.212 & 0.41 \\
\hline Exp4 & Farm experience (more than 20 years) & 0.580 & 0.49 \\
\hline Days1 & On-farm work (less than 60 days) & 0.417 & 0.49 \\
\hline Days2 & On-farm work (60-149 days) & 0.381 & 0.49 \\
\hline Days3 & On-farm work (equal to or greater than 150 days) & 0.202 & 0.40 \\
\hline \multicolumn{4}{|l|}{$\begin{array}{c}\text { HH (Household) } \\
\text { characteristics }\end{array}$} \\
\hline HH size & Household size (persons) & 3.664 & 2.06 \\
\hline HH labor & Household members working on the farm (\%) & 0.638 & 0.29 \\
\hline Land & Farmland used for crop production (are) & 76.739 & 89.02 \\
\hline
\end{tabular}

Due to high correlations of monthly climate data (Table 2), the seasonal averages in temperature and precipitation are used to capture the effects of climate on crop choice and production of the three staple food commodities. The four seasons are defined as: spring 
(March, April, May), summer (June, July, August, September), fall (October, November) and winter (December, January, February). It was indicated that summer is one month longer than before in Taiwan [43]. Therefore, summer is composed of four months in the present study.

\subsection{Research Design}

The effect of climate variables on staple food production is modeled in a two-stage framework as in previous studies, for example, [33,34,38,40]. The two-stage modeling is a generalization of the selection correction model [46]. In stage 1, the farm household's choice of a staple food to produce is based on the random utility theory and estimated through a multinomial logit (MNL) model. The second stage incorporates the selection-bias correction terms into the explanation of the production value of staple foods.

According to the random utility model $[47,48]$, the choice of crop results from the comparison of indirect utility associated with different choices by the decision unit, which is the farm household in our case. There are three crops considered in this study: rice, vegetable and fruit. Let the indirect utility associated with the choice of the $m$ th crop be denoted by $U_{m}^{*}$, where $m=1$ denotes rice, $m=2$ denotes vegetables and $m=3$ denotes fruits. The choice of the sth crop can be expressed as

$$
U_{s}^{*}>\max _{m=1,2,3, m \neq s} U_{m}^{*}
$$

Previous studies based on the Ricardian approach confirmed the influential role of climate variables in crop choice, for example, $[34,37,49,50]$. The indirect utility is thus further assumed to be a linear function of the characteristics of the farm, farm households and principal operators as well as the climate variables

$$
U_{m}^{*}=\mathbf{W} \boldsymbol{\alpha}_{m}+\mathbf{X} \boldsymbol{\beta}_{m}+\eta_{m}, m=1,2,3
$$

In the above equation, $\mathbf{W}$ and $\mathbf{X}$ are, respectively, the vector of climatic conditions and the vector of socio-characteristics. $\boldsymbol{\alpha}_{m}$ and $\boldsymbol{\beta}_{m}$ are the vectors of parameters and $\eta_{m}$ is the random disturbance terms. It is assumed that the difference in the indirect utility between the crop chosen $(s)$ and that not chosen $(m \neq s)$ can be expressed as

$$
\begin{gathered}
\varepsilon_{s}=\max _{m \neq s}\left(U_{m}^{*}-U_{s}^{*}\right) \\
=\max _{m \neq s}\left(\mathbf{W} \boldsymbol{\alpha}_{m}+\mathbf{X} \boldsymbol{\beta}_{m}+\eta_{m}-\mathbf{W} \boldsymbol{\alpha}_{s}-\mathbf{X} \boldsymbol{\beta}_{s}-\eta_{s}\right)
\end{gathered}
$$

According to (1), the difference between the indirect utility of crop choices defined in (3) is less than zero, and the conditional probability of the choice of the sth crop is equal to the conditional probability of negative utility difference.

Following previous research, the choice of the three staple foods is basically unordered in nature, and thus is estimated through the MNL model under the assumption that $\left(\varepsilon_{i 1}, \varepsilon_{i 2}, \varepsilon_{i 3}\right)$ follows a multinomial logistic distribution. Let the indicator variable, $D_{s}$, take the value of 1 when the sth crop is chosen and 0 otherwise. The probability that the $i$ th farm operator chooses the sth crop can be expressed as

$$
\operatorname{Prob}\left(D_{s}=1 \mid \mathbf{X}, \mathbf{W}\right)=\frac{\exp \left(\mathbf{W} \boldsymbol{\alpha}_{s}+\mathbf{X} \boldsymbol{\beta}_{s}\right)}{\sum_{m=1}^{3} \exp \left(\mathbf{W} \boldsymbol{\alpha}_{m}+\mathbf{X} \boldsymbol{\beta}_{m}\right)}
$$

The MNL model can be estimated through the following log-likelihood function:

$$
L=\sum_{i=1}^{N} \sum_{m=1}^{3} D_{i m} \cdot \log \left[\operatorname{Prob}\left(D_{m}=1 \mid \mathbf{X}_{i}, \mathbf{W}_{i}\right)\right]
$$


Note that in the likelihood function in (5), the $N$ observations are clustered into $c$ clusters for each of the climate variables to take into account the spatial correlation of the observations located at the same cluster.

Possible correlation between crop choice and the production value of the crop is corrected by including three selection correction terms into the production-value-determination equation [47]. The effect of the climate variables on the production of the sth staple food commodity is then estimated as the following

$$
E\left(Y_{i} \mid D_{s}=1\right)=\mathbf{Z}_{i} \boldsymbol{\gamma}_{s}+\mathbf{W}_{c} \boldsymbol{\kappa}_{s}+\sigma \cdot \sum_{i \neq m}^{3} r_{i} \cdot\left(\frac{P_{i} \cdot \ln P_{i}}{1-P_{i}}+\ln P_{m}\right)
$$

where $Y_{i}$ denotes the production value of the sth commodity produced by the $i$ th farm household, which is located in county $c ; \mathbf{Z}$ is the explanatory variables affecting the production value of the $s$ th commodity other than the climate variables. The vectors of parameters are denoted by $\gamma$ and $\kappa$, respectively. It is important to note that there is assumed independence across clusters (counties) but correlation within clusters (counties).

\section{Results}

\subsection{The Choice of Crop Commodity}

Coefficients for the stage 1 (MNL) model of the farm household's choice of the three staple foods are obtained through the estimation of the likelihood function specified in Equation (5). Table 2 reports the estimates of the MNL estimate with the rice households as the reference group while controlling for the climatic conditions and the socio-economic characteristics of the principal operator or the farm household. The estimates of crop choice reported in Table 2 are interpreted in a relative sense, i.e., the coefficient of one predictor in the $k$ th crop choice is a measure of the effect of the predictor on the probability of choosing the $k$ th crop over the reference group. We estimate two different specifications in Table 2. The first four columns are the MNL model estimates, controlling only for seasonal temperature and precipitation conditions.

The results in Table 2 are, in general, unsatisfactory, since only one coefficient is a significant determinant of the choice of vegetables relative to rice. The last four columns control for both the climatic conditions and the socio-economic characteristics of the principal operator and the farm household. After controlling for the socio-economic characteristics, the structural Ricardian model estimates are more satisfactory in terms of the individual significance of the climate variables and their squared terms. Therefore, in the following analysis, we calculated the selection correction terms according to the estimates reported in columns 5 and 7 in Table 2.

According to the results in Table 2, the principal operator's socio-economic characteristics, including age, educational level, years of farming experience and on-the-farm workdays, are important determinants for their choice of staple food commodities. Additionally, seasonal average temperatures and their squared terms, and seasonal average precipitation and their squared terms, are the major determinants of staple food production in Taiwan. The results suggest the nonlinear effect of seasonal average temperature and precipitation on the farm household's choice of staple food commodity. 
Table 2. Maximum likelihood estimates of the multinomial logit (MNL) model.

\begin{tabular}{|c|c|c|c|c|c|c|c|c|c|c|c|c|}
\hline \multirow{2}{*}{ Variable } & \multicolumn{3}{|c|}{ Vegetables } & \multicolumn{3}{|c|}{ Fruits } & \multicolumn{3}{|c|}{ Vegetables } & \multicolumn{3}{|l|}{ Fruits } \\
\hline & Coef. & & S.E. & Coef. & & S.E. & Coef. & & S.E. & Coef. & & S.E. \\
\hline \multicolumn{13}{|l|}{ Seasonal temp } \\
\hline Spring & -5.5771 & & 18.38 & -20.8146 & $* * *$ & 2.95 & -11.0578 & & 13.98 & -26.2727 & $* * *$ & 4.83 \\
\hline Summer & 10.4691 & & 9.92 & -18.5363 & $* * *$ & 2.28 & 17.4990 & $* *$ & 7.31 & -12.8134 & $* * *$ & 3.15 \\
\hline Fall & -7.5452 & & 5.67 & 3.5163 & $* * *$ & 1.06 & -8.0489 & $*$ & 4.11 & 0.6089 & & 2.40 \\
\hline Winter & 10.7260 & & 12.11 & 12.1159 & $* * *$ & 2.34 & 11.2718 & & 8.97 & 14.3472 & $* * *$ & 3.46 \\
\hline \multicolumn{13}{|l|}{ Temperature sq } \\
\hline Spring & 0.1546 & & 0.44 & 0.5614 & $* * *$ & 0.08 & 0.2706 & & 0.34 & 0.6885 & $* * *$ & 0.12 \\
\hline Summer & -0.1775 & & 0.15 & 0.2592 & $* * *$ & 0.03 & -0.2784 & $* *$ & 0.11 & 0.1684 & $* * *$ & 0.05 \\
\hline Fall & 0.1071 & & 0.12 & -0.0017 & & 0.03 & 0.0802 & & 0.09 & 0.0302 & & 0.05 \\
\hline Winter & -0.3248 & & 0.40 & -0.4788 & $* * *$ & 0.08 & -0.3206 & & 0.29 & -0.5292 & $* * *$ & 0.11 \\
\hline \multicolumn{13}{|l|}{$\begin{array}{c}\text { Seasonal } \\
\text { rainfall }\end{array}$} \\
\hline Spring & -0.0487 & & 0.06 & -0.1864 & $* * *$ & 0.01 & -0.1200 & $* * *$ & 0.05 & -0.2563 & $* * *$ & 0.03 \\
\hline Summer & -0.0379 & & 0.04 & -0.0571 & $* * *$ & 0.01 & -0.0354 & & 0.03 & -0.0655 & $* * *$ & 0.01 \\
\hline Fall & 0.0035 & & 0.01 & 0.0345 & $* * *$ & 0.00 & 0.0010 & & 0.01 & 0.0302 & $* * *$ & 0.00 \\
\hline Winter & 0.0540 & & 0.07 & 0.0514 & $* *$ & 0.02 & 0.0569 & & 0.05 & 0.0877 & $* *$ & 0.04 \\
\hline \multicolumn{13}{|l|}{ Rainfall sq } \\
\hline Spring & 0.0001 & & 0.00 & 0.0006 & $* * *$ & 0.00 & 0.0004 & $* *$ & 0.00 & 0.0009 & $* * *$ & 0.00 \\
\hline Summer & 0.0001 & & 0.00 & 0.0001 & $* * *$ & 0.00 & 0.0001 & & 0.00 & 0.0001 & $* * *$ & 0.00 \\
\hline Fall & -0.0001 & * & 0.00 & -0.0001 & $* * *$ & 0.00 & 0.0000 & $* *$ & 0.00 & -0.0001 & $* * *$ & 0.00 \\
\hline Winter & 0.0000 & & 0.00 & -0.0002 & $* * *$ & 0.00 & -0.0002 & & 0.00 & -0.0005 & $* *$ & 0.00 \\
\hline \multicolumn{13}{|l|}{ Socio-economic } \\
\hline Male & & & & & & & -0.1783 & & 0.12 & 0.0807 & & 0.07 \\
\hline Age2 & & & & & & & -0.2635 & & 0.18 & -0.1297 & & 0.16 \\
\hline Age3 & & & & & & & -0.5095 & $* *$ & 0.22 & -0.4244 & $* *$ & 0.18 \\
\hline Age4 & & & & & & & -0.7505 & $* * *$ & 0.27 & -0.5890 & $* *$ & 0.25 \\
\hline Age5 & & & & & & & -0.8833 & $* * *$ & 0.23 & -0.5617 & $* *$ & 0.25 \\
\hline Junior high & & & & & & & 0.0591 & & 0.12 & 0.1955 & $*$ & 0.10 \\
\hline Senior high & & & & & & & -0.2021 & & 0.14 & 0.2049 & & 0.14 \\
\hline College & & & & & & & -0.4661 & $* *$ & 0.18 & 0.0626 & & 0.23 \\
\hline Exp2 & & & & & & & 0.0320 & & 0.29 & 0.3142 & & 0.23 \\
\hline Exp3 & & & & & & & 0.3825 & $*$ & 0.20 & 0.1767 & & 0.19 \\
\hline Exp4 & & & & & & & 0.2612 & $* *$ & 0.13 & 0.3214 & $* * *$ & 0.11 \\
\hline Days2 & & & & & & & 0.9957 & $* * *$ & 0.21 & 0.9182 & $* * *$ & 0.30 \\
\hline Days3 & & & & & & & 2.1816 & $* * *$ & 0.32 & 2.0915 & $* * *$ & 0.36 \\
\hline Land & & & & & & & -0.0029 & $* * *$ & 0.00 & -0.0002 & & 0.00 \\
\hline HH size & & & & & & & 0.1052 & $* *$ & 0.05 & 0.0806 & $* *$ & 0.03 \\
\hline HH labor & & & & & & & 1.0956 & $* * *$ & 0.39 & 1.0395 & $* * *$ & 0.34 \\
\hline _Cons & -71.2235 & & 177 & 356.805 & & 43.57 & -100.1176 & & 134.95 & 358.1025 & $* * *$ & 65.41 \\
\hline No. of obs & 955 & & & 1474 & & & 955 & & & 1474 & & \\
\hline
\end{tabular}

Note: ${ }^{*},{ }^{* *}$ and ${ }^{* * *}$ denote significant at the $10 \%, 5 \%$ and $1 \%$ significance level.

\subsection{Estimating the Structural Ricardian Model}

Our stage 2 estimation of the structural Ricardian model incorporates the three selection-correction terms into the clustered regression of the per-unit product value. In this stage, the controlled variables include the social-economic characteristics of the farm household and principal operator, seasonal temperatures and the squared terms, and seasonal precipitations and the squared terms. The estimates of the clustered regression conditioned on the farm household's crop choice are reported in Table 3.

Coefficient estimates of the three selection-correction terms are significant for rice farms but not significant for the other two staple food growers. Therefore, results from uncorrected regression of the vegetable and fruit households are reported in columns 3-6 in Table 3. Based on the results in Table 3, seasonal temperatures and precipitations are found to exhibit non-linear impacts on the production of each of the three staple foods. 
Table 3. Clustered regression conditioned on choice of staple food commodity.

\begin{tabular}{|c|c|c|c|c|c|c|c|c|c|}
\hline \multirow{2}{*}{ Variable } & \multicolumn{3}{|c|}{ Rice } & \multicolumn{3}{|c|}{ Vegetables } & \multicolumn{3}{|c|}{ Fruits } \\
\hline & Coef. & & Std. Err. & Coef. & & Std. Err. & Coef. & & Std. Err. \\
\hline \multicolumn{10}{|l|}{ Seasonal temp } \\
\hline spring & $99,667.82$ & * & $50,650.42$ & $57,722.10$ & & $37,019.12$ & 8649.404 & & $27,169.72$ \\
\hline summer & $64,089.40$ & $*$ & $31,053.26$ & $29,068.89$ & & $19,671.57$ & $13,578.69$ & & $15,010.17$ \\
\hline fall & $-15,822.99$ & $* * *$ & 4064.56 & $-57,617.96$ & $* * *$ & 8740 & $-39,651.51$ & $* * *$ & 7140.18 \\
\hline winter & $-45,873.56$ & & $26,783.95$ & $-11,179.70$ & & $18,820.64$ & 1160.545 & & $17,882.19$ \\
\hline \multicolumn{10}{|l|}{ Temperature sq } \\
\hline spring & -2630.50 & * & 1332.38 & -1279.33 & & 875.01 & -124.7959 & & 681.49 \\
\hline summer & -868.88 & * & 419.96 & -493.95 & $*$ & 280.6 & -260.6547 & & 226.6 \\
\hline fall & 58.99 & & 65.69 & 991.98 & $* * *$ & 214.3 & 719.5156 & $* * *$ & 156.83 \\
\hline winter & 1834.12 & * & 1007.98 & 520.62 & & 609.03 & 60.359 & & 589.97 \\
\hline \multicolumn{10}{|l|}{ Seasonal rainfall } \\
\hline spring & 941.71 & * & 495.53 & -78.87 & & 129.51 & -116.4395 & & 126.86 \\
\hline summer & 242.24 & * & 125.04 & -52.18 & & 62.22 & -69.60886 & & 66.46 \\
\hline fall & -130.16 & $* *$ & 60.95 & -43.50 & $* *$ & 19.51 & -21.9075 & & 16.3 \\
\hline winter & -377.69 & $* *$ & 172.41 & 9.22 & & 124.1 & 190.4126 & $*$ & 102.68 \\
\hline \multicolumn{10}{|l|}{ Rainfall sq } \\
\hline spring & -3.30 & * & 1.73 & 0.17 & & 0.49 & 0.4660478 & & 0.45 \\
\hline summer & -0.49 & * & 0.26 & 0.10 & & 0.11 & 0.1015217 & & 0.13 \\
\hline fall & 0.26 & $*$ & 0.13 & 0.05 & & 0.05 & 0.0248407 & & 0.04 \\
\hline winter & 2.10 & $* *$ & 0.95 & -0.02 & & 0.32 & -1.073143 & $* *$ & 0.39 \\
\hline \multicolumn{10}{|l|}{ Selection terms } \\
\hline Rice & -978.38 & * & 527.79 & & & & & & \\
\hline Vegetables & -216.26 & * & 109.57 & & & & & & \\
\hline Fruits & 1301.23 & * & 638.22 & & & & & & \\
\hline $\begin{array}{c}\text { Control for } \\
\text { socio-econ vars }\end{array}$ & yes & & & & yes & & & yes & \\
\hline _cons & $-1,468,703.00$ & * & $757,124.10$ & $-244,460.70$ & & & $178,770.6$ & & $345,465.6$ \\
\hline
\end{tabular}

Note: ${ }^{*}, * *$ and ${ }^{* * *}$ denote significant at the $10 \%, 5 \%$ and $1 \%$ significance level.

\section{Discussion}

The effect of the climate variables on the choice of major crop to produce is nonlinear, since some of the coefficients for the squared terms are significant (Table 2). The coefficient estimate from the MNL model is not a straightforward measure of the effects, especially when there are squared terms involved. In order to provide a more intuitive description of the impact of climatic conditions on the farm household's crop choice, we present the predictive margin plots by varying each of the climate variables over the whole dataset and calculate the averages of predicted probability for each crop choice. Figures 3 and 4 illustrate the effects of seasonal increases in temperature on the probability of crop choice. 

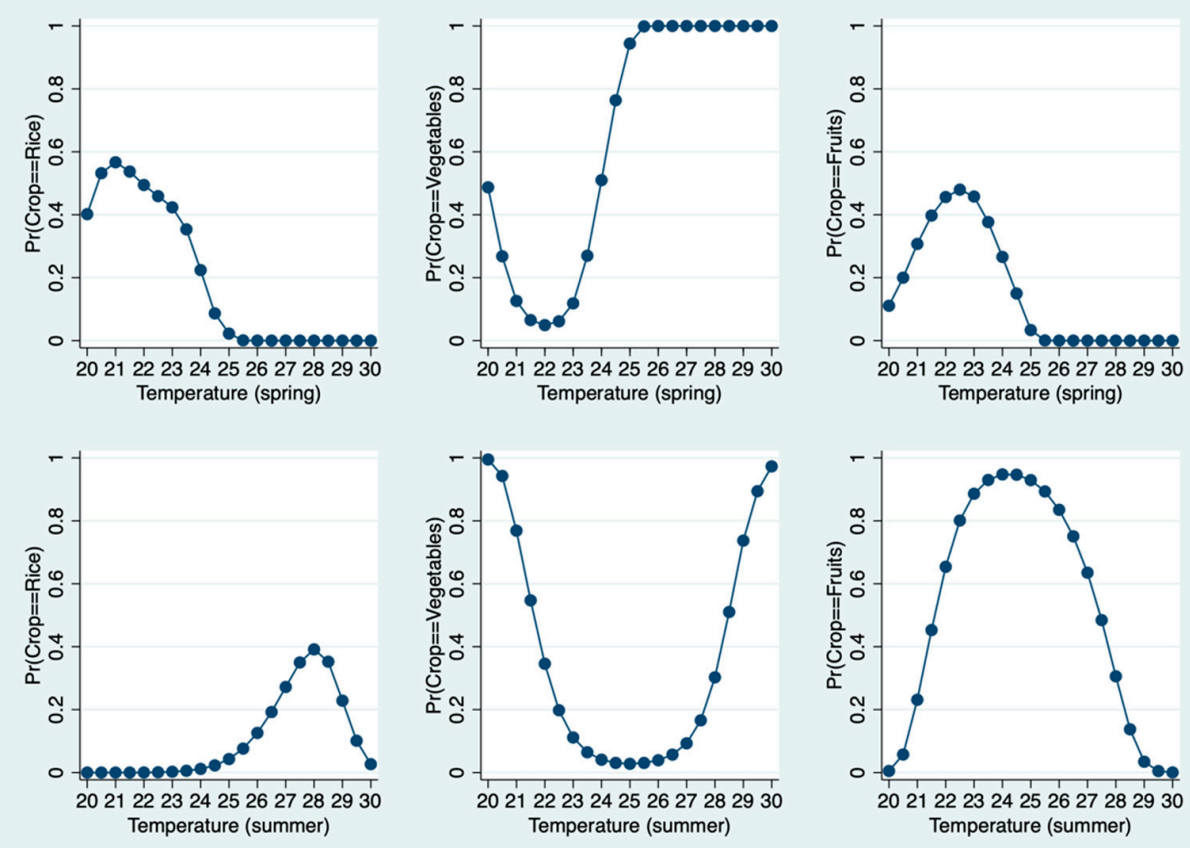

Figure 3. Predictive effect of temperature (spring, summer).
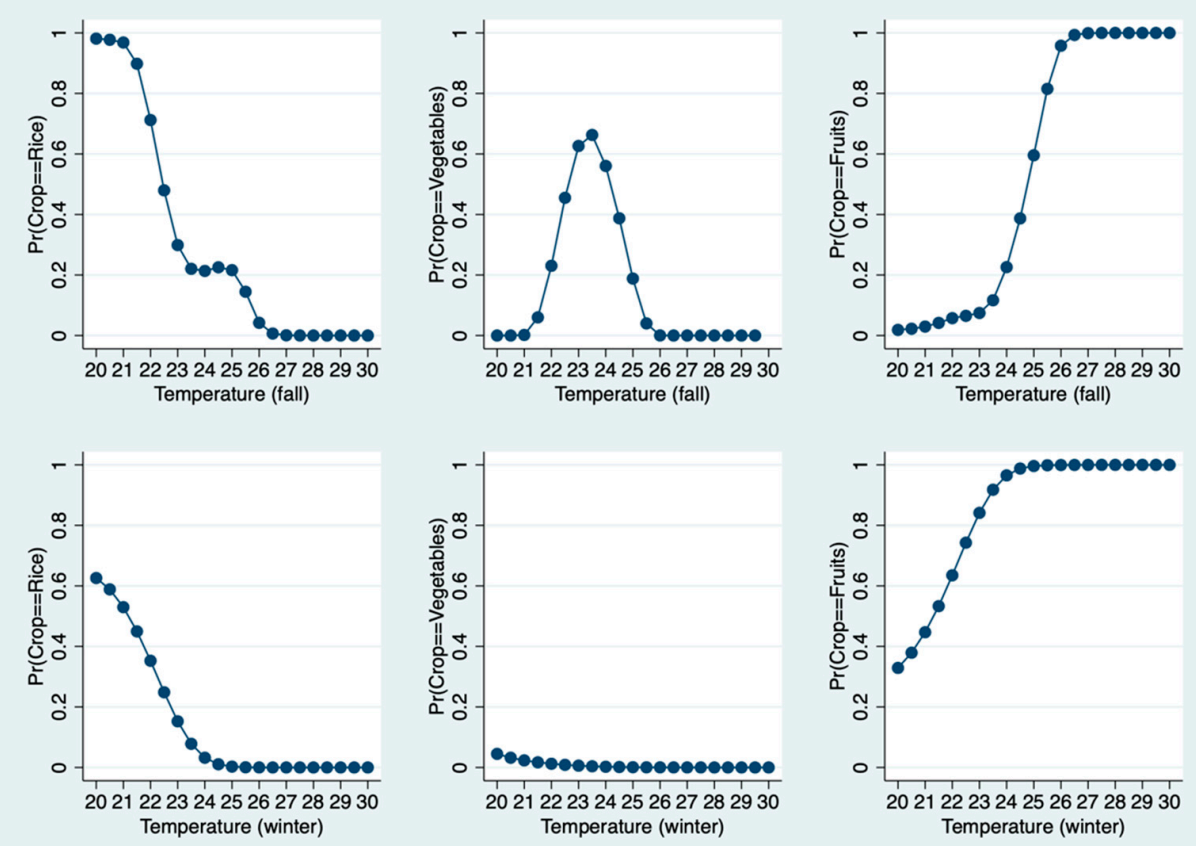

Figure 4. Predictive effect of temperature (fall, winter).

The upper panel of Figure 3 shows that farm households are inclined to produce vegetables when spring is warm. The average temperature in spring is $23.16^{\circ} \mathrm{C}$; when it is $1^{\circ} \mathrm{C}$ warmer, more than half of the farm household will choose to produce vegetables. However, the lower panel of Figure 3 reveals that there is a higher probability of choosing to produce fruits when the temperature is below the average $\left(27.74^{\circ} \mathrm{C}\right)$ in summer. Nonetheless, when the temperature is higher than the average, farm households will switch to producing vegetables. Figure 4 illustrates the increasing tendency to produce fruits in the fall (upper 
panel) and in the winter (lower panel).

The effects of seasonal average precipitations are graphed in Figures 5 and 6. Spring and summer are the wet seasons in Taiwan. The upper panel of Figure 5 indicates that increasing rainfall when it's below the average level of $175 \mathrm{~mm}$ in the spring will increase the farm household's probability of producing rice. However, increasing precipitation at higher than average levels in the spring will eventually induce the switch to vegetables.
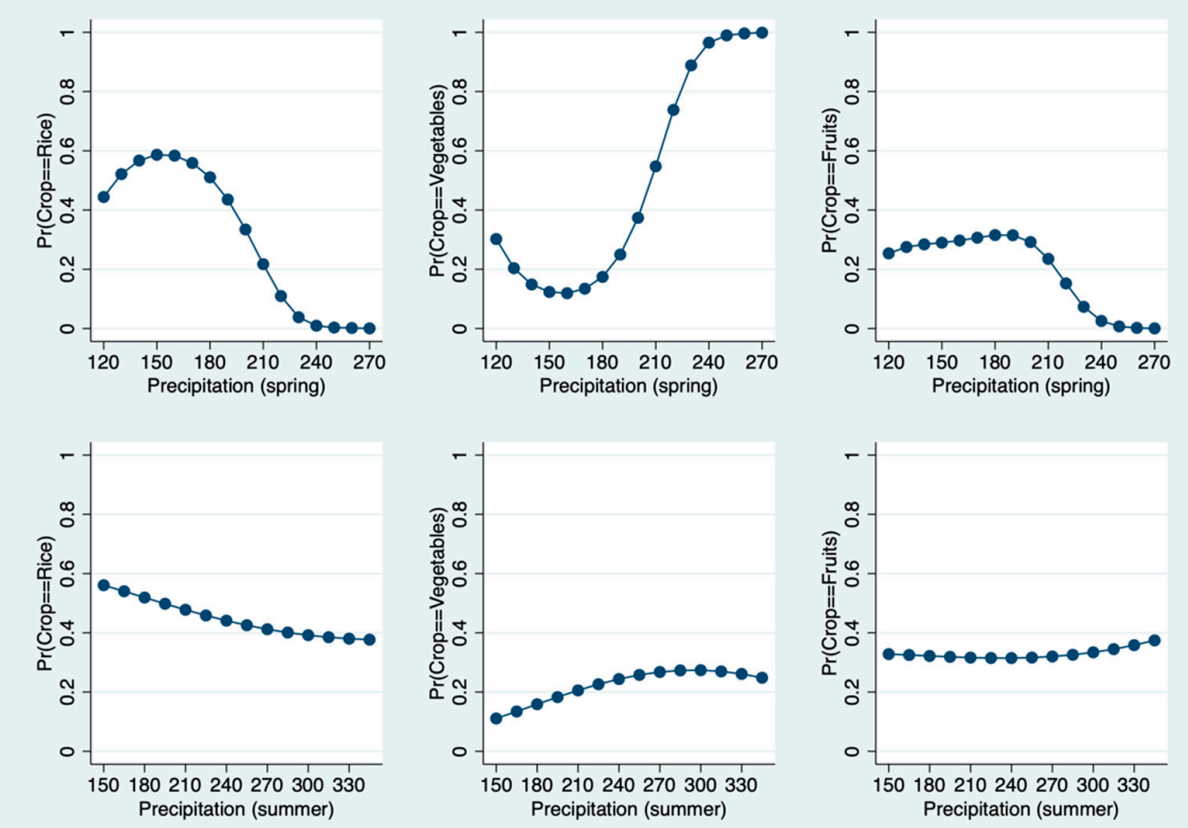

Figure 5. Predictive effect of precipitation (spring, summer).
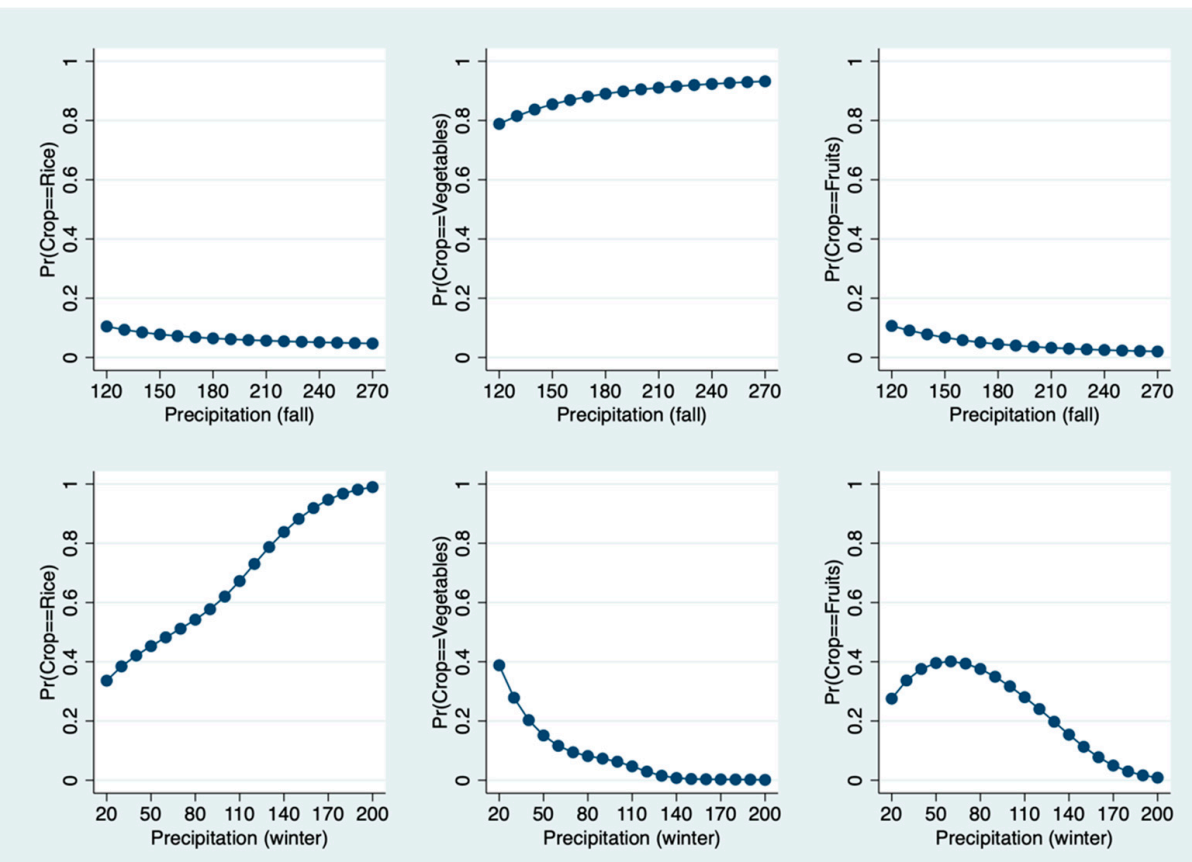

Figure 6. Predictive effect of precipitation (fall, winter). 
The lower panel of Figure 5 nonetheless indicates that the probability of crop choice is relatively stable relative to the increase in precipitation in the summer. Figure 6 portrays the effect of increasing precipitation during the dry season (fall and winter) in Taiwan. The choice of vegetables remains dominant in the fall (upper panel), while more rainfall in the winter will persistently increase the farm household's choice of producing rice (lower panel).

In order to predict the effect of variations in climatic conditions on the production value of the staple foods, we report the marginal effects of the climate variables in Table 4. The F-statistic reported in Table 4 is the test for the joint significance of the seasonal temperature (precipitation) and its squared term. According to the estimates reported in Table 4, high temperature in the fall is found to have a unanimous dampening effect on the production of staple foods, which is, in order, $-\$ 790$ (vegetables), $-\$ 430$ (rice) and $-\$ 50$ (fruits). The results suggest the impacts of seasonal temperature variations in general vary significantly across the staple food commodity chosen by the farm household. Among the three staple food crops, vegetables seem to be more sensitive to seasonal variations in temperature. There are two reasons that can explain this result. First, the growth cycles of vegetables are generally shorter than rice and fruits, which may lead to more sensitive responses of vegetables to seasonal temperature variations. Second, based on the farm-household frequency distribution of major commodities in the 2015 Agriculture Census data [51], we calculated the proportion of vegetable households producing mainly leafy vegetables and found that the share of leafy vegetables was around $47 \%$. Since leafy vegetables are relatively more vulnerable to high/low temperatures, another reason to explain why vegetables are more sensitive to temperatures is due to the fact that almost half of the vegetable households produce mainly leafy vegetables.

Table 4. Predicted effects of temperature or precipitation on staple food production (USD per-unit farmland).

\begin{tabular}{|c|c|c|c|c|c|c|c|c|}
\hline \multirow{2}{*}{$\begin{array}{l}\text { Commodity/ } \\
\text { Season }\end{array}$} & \multicolumn{4}{|c|}{ Temperature } & \multicolumn{4}{|c|}{ Precipitation } \\
\hline & Mean & & Std. Dev. & F-stat & Mean & & Std. Dev. & F-stat \\
\hline \multicolumn{9}{|l|}{ Rice/ } \\
\hline Spring & -712.897 & & 7.22 & 2.33 & -8.135 & $*$ & 0.19 & 3.61 \\
\hline Summer & 522.128 & & 1.57 & 2.16 & 0.604 & $*$ & 0.06 & 3.75 \\
\hline Fall & -432.440 & $* * *$ & 0.13 & 8.80 & -3.274 & $* *$ & 0.06 & 5.11 \\
\hline Winter & 593.887 & $* * *$ & 4.23 & 9.01 & -7.061 & & 0.15 & 2.47 \\
\hline \multicolumn{9}{|l|}{ Vegetables/ } \\
\hline Spring & -2944.631 & $* * *$ & 38.49 & 9.45 & -1.044 & & 0.00 & 1.73 \\
\hline Summer & 1163.105 & & 3.82 & 0.96 & -0.051 & & 0.01 & 0.55 \\
\hline Fall & -792.191 & $* *$ & 0.87 & 4.48 & -1.522 & $* * *$ & 0.01 & 8.53 \\
\hline Winter & 2306.079 & $* *$ & 26.45 & 4.77 & 0.596 & & 0.00 & 0.05 \\
\hline \multicolumn{9}{|l|}{ Fruits/ } \\
\hline Spring & -278.334 & & 4.26 & 2.15 & 1.528 & & 0.03 & 2.29 \\
\hline Summer & 45.317 & & 0.12 & 0.16 & -0.572 & $* *$ & 0.02 & 6.02 \\
\hline Fall & -46.642 & $* *$ & 1.05 & 3.98 & -0.594 & & 0.00 & 1.4 \\
\hline Winter & 351.390 & & 4.18 & 0.19 & 4.495 & $* *$ & 0.05 & 5.89 \\
\hline
\end{tabular}

Note: 1 USD $=30$ NTD; ${ }^{*}{ }^{* *}$ and ${ }^{* *}$ denote significant at the $10 \%, 5 \%$ and $1 \%$ significance level.

Taiwan is characterized by clear spatial variations and seasonal variations in rainfall. Similar to the effect of variations in seasonal average temperature, the effect of seasonal precipitation variations is found to vary significantly across the staple food commodity chosen by the farm household. Nonetheless, our results indicate that increasing precipitation in the winter can significantly increase the production of fruits which are heavily concentrated in southern Taiwan.

A comparison of the three staple food commodities indicates that, among the three staple foods, vegetable production is found to be affected by high temperatures to the largest extent. Although the negative impact of high temperature in spring and fall may be partly offset by the positive effect of higher temperature in winter, vegetables are the most 
vulnerable to the variations in seasonal average temperature among the three crops. As for the effect of precipitation, we found that rice production is influenced to the greatest extent, due to increasing precipitation in the spring.

To assess the impact of climate change on staple foods production, we perform simulation analysis under four Representative Concentration Pathways (RCPs) scenarios. The four scenarios in Table 5 (RCP2.6, RCP4.5, RCP6.0 and RCP8.5) are projected change in climate parameters for Taiwan during the time period of 2021-2100, based on IPCC AR5 (the Fifth Assessment Report of the Intergovernmental Panel on Climate Change) [52].

Table 5. Scenarios of climate change.

\begin{tabular}{|c|c|c|c|c|c|c|c|c|c|}
\hline \multirow[t]{2}{*}{ Year } & \multirow[t]{2}{*}{ Area } & \multicolumn{4}{|c|}{$\begin{array}{c}\text { Change in Temperature } \\
\left({ }^{\circ} \mathrm{C}\right)\end{array}$} & \multicolumn{4}{|c|}{$\begin{array}{l}\text { Change in Precipitation } \\
(\mathrm{mm})\end{array}$} \\
\hline & & RCP2.6 & RCP4.5 & RCP6.0 & RCP8.5 & RCP2.6 & RCP4.5 & RCP6.0 & RCP8.5 \\
\hline \multirow[t]{4}{*}{ 2021-2040 } & North & 0.64 & 0.68 & 0.61 & 0.78 & 41.1 & 47.1 & 36.6 & 78 \\
\hline & Central & 0.64 & 0.68 & 0.62 & 0.78 & 45.3 & 55.8 & 54.9 & 102.9 \\
\hline & South & 0.62 & 0.66 & 0.62 & 0.76 & 48.9 & 56.4 & 49.2 & 119.1 \\
\hline & East & 0.62 & 0.65 & 0.61 & 0.76 & 49.2 & 38.1 & 34.8 & 82.5 \\
\hline \multirow[t]{4}{*}{ 2041-2060 } & North & 0.95 & 1.17 & 0.94 & 1.51 & 124.8 & 111.6 & 3.3 & 27.9 \\
\hline & Central & 0.93 & 1.15 & 0.94 & 1.5 & 127.8 & 123 & -37.5 & 21.3 \\
\hline & South & 0.9 & 1.13 & 0.92 & 1.46 & 148.8 & 134.7 & -222.3 & 22.5 \\
\hline & East & 0.91 & 1.13 & 0.91 & 1.46 & 120.6 & 104.4 & -99.3 & 21.3 \\
\hline \multirow[t]{4}{*}{ 2061-2080 } & North & 0.89 & 1.47 & 1.43 & 2.36 & 141.6 & 147.3 & 49.8 & 71.7 \\
\hline & Central & 0.88 & 1.45 & 1.43 & 2.32 & 147 & 152.1 & 69.3 & 83.1 \\
\hline & South & 0.86 & 1.41 & 1.40 & 2.27 & 142.2 & 150.9 & 68.4 & 99.6 \\
\hline & East & 0.86 & 1.41 & 1.39 & 2.27 & 128.4 & 125.1 & 60.3 & 70.2 \\
\hline \multirow[t]{4}{*}{ 2081-2100 } & North & 0.77 & 1.57 & 1.98 & 3.16 & 154.8 & 108.9 & 125.4 & 49.8 \\
\hline & Central & 0.78 & 1.56 & 1.96 & 3.1 & 161.7 & 124.8 & 150 & 39.3 \\
\hline & South & 0.26 & 1.52 & 1.91 & 3.03 & 144.6 & 132.9 & 143.1 & 54.9 \\
\hline & East & 0.76 & 1.52 & 1.91 & 3.04 & 120.9 & 96.6 & 122.7 & 52.8 \\
\hline
\end{tabular}

RCP2.6 is a scenario with global warming making very mild progress, and thus the scenario with the least increase in temperature and the largest scale of rainfall increase. A relatively modest progression of global warming is projected under RCP4.5 and RCP6.0. Relatively speaking, RCP6.0 has a larger scale of temperature increase compared to RCP4.5, especially in 2081-2100. On the other hand, precipitation is projected to increase steadily under RCP4.5, whereas there is a decrease in precipitation, ranging from -37.5 to $-222.3 \mathrm{~mm}$ in 2041-2060, and a mild increase in the following two decades under RCP6.0. RCP8.5 is the scenario with the most severe progression in global warming. Under RCP8.5, the temperature increases to the largest extent, while there seems to be some cyclical movement in precipitation change among each 20-year interval. The increase in precipitation in 2021-2040 ranges from 78 to $119.1 \mathrm{~mm}$, which is much larger in scale compared with the 21.3-27.9 mm precipitation change in 2041-2060. The increase in precipitation in 2061-2080 is back to the high in 2021-2040 with the increment ranges between 70.2 and $99.6 \mathrm{~mm}$, which then goes back to a mild change of 39.3-54.9 mm during 2081-2100. The projections in Table 5 reveals spatial variations in the change of temperatures and precipitations. Central and northern Taiwan are projected to exhibit a larger-scale change in temperature, whereas the central and southern areas have larger precipitation changes relative to the north and the east.

Climate change impact assessment under the four scenarios are reported in Table 6. The results indicate that climate change lowers the production value of rice under all four scenarios with only three exceptions, which suggest the adverse effect of climate change on rice production. As expected, there appear to be spatial differences in terms of the negative effect of climate change on rice production. Central and southern Taiwan are projected to experience more severe loss than in other parts of the island. Under RCP6.0, the adverse 
effect of climate change on rice production reaches the high of approximately $\$ 2900$ in the last two decades of the century.

Table 6. Impacts of selected climate change scenarios (USD per-unit farmland).

\begin{tabular}{|c|c|c|c|c|c|c|c|c|c|c|c|c|}
\hline \multirow[t]{2}{*}{ Year/Area } & \multicolumn{4}{|c|}{$\begin{array}{c}\text { Rice } \\
\text { Change in Production Value }\end{array}$} & \multicolumn{4}{|c|}{$\begin{array}{c}\text { Vegetables } \\
\text { Change in Production Value }\end{array}$} & \multicolumn{4}{|c|}{$\begin{array}{c}\text { Fruits } \\
\text { Change in Production Value }\end{array}$} \\
\hline & RCP2.6 & RCP4.5 & RCP6.0 & RCP8.5 & RCP2.6 & RCP4.5 & RCP6.0 & RCP8.5 & RCP2.6 & RCP4.5 & RCP6.0 & RCP8.5 \\
\hline \multicolumn{13}{|l|}{ 2021-2040 } \\
\hline North & -753 & -861 & -672 & -1416 & -56 & -66 & -48 & -124 & 246 & 278 & 222 & 435 \\
\hline Central & -828 & -1017 & -999 & -1861 & -64 & -84 & -85 & -175 & 266 & 320 & 311 & 556 \\
\hline South & -892 & -1027 & -897 & -2150 & -72 & -86 & -73 & -208 & 282 & 321 & 283 & 633 \\
\hline East & -897 & -700 & -640 & -1496 & -73 & -49 & -44 & -134 & 283 & 232 & 213 & 455 \\
\hline \multicolumn{13}{|l|}{ 2041-2060 } \\
\hline North & -2258 & -2028 & -87 & -543 & -212 & -176 & 33 & 8 & 674 & 626 & 83 & 244 \\
\hline Central & -2311 & -2231 & 642 & -425 & -219 & -200 & 116 & 21 & 687 & 680 & -115 & 211 \\
\hline South & -2685 & -2440 & 3945 & -445 & -262 & -224 & 488 & 17 & 787 & 735 & -1014 & 214 \\
\hline East & -2181 & -1898 & 1747 & -423 & -205 & -163 & 239 & 19 & 651 & 588 & -417 & 208 \\
\hline \multicolumn{13}{|l|}{ 2061-2080 } \\
\hline North & -2556 & -2675 & -932 & -1350 & -248 & -235 & -40 & -45 & 752 & 821 & 344 & 518 \\
\hline Central & -2652 & -2760 & -1280 & -1553 & -260 & -246 & -79 & -69 & 777 & 843 & 439 & 570 \\
\hline South & -2566 & -2737 & -1263 & -1846 & -251 & -245 & -79 & -105 & 752 & 834 & 433 & 647 \\
\hline East & -2319 & -2276 & -1118 & -1321 & -223 & -193 & -63 & -45 & 685 & 709 & 393 & 504 \\
\hline \multicolumn{13}{|l|}{$2081-2100$} \\
\hline North & -2788 & -1992 & -2299 & -982 & -280 & -153 & -169 & 34 & 807 & 642 & 751 & 469 \\
\hline Central & -2912 & -2275 & -2737 & -793 & -294 & -186 & -220 & 52 & 841 & 718 & 869 & 413 \\
\hline South & -2591 & -2419 & -2613 & -1070 & -281 & -204 & -208 & 18 & 721 & 755 & 832 & 484 \\
\hline East & -2182 & -1770 & -2248 & -1032 & -212 & -131 & -167 & 23 & 642 & 578 & 733 & 475 \\
\hline
\end{tabular}

Note: 1 USD = 30 NTD.

With a few exceptions, climate change appears to have an adverse effect on the production of vegetables, which are smaller in size compared to those for rice. There are also spatial differences in the simulated effect of climate change on vegetable production. Similar to rice, climate change impact on vegetables is larger in the northern and central areas of Taiwan. There is a gradual increase in terms of the size of the negative effect under RCP2.6 and RCP4.5. However, under RCP6.0 and RCP8.5, the effects of climate change switch in signs during the entire time span. The impact of climate change on fruits are different from the other two staple foods. The simulated results suggest that there is a gradual increase in terms of the size of the effect on the production of fruits. Except for RCP8.5, the positive impacts of climate change start with a size of around \$210-\$320 in 2021-2040, which later increase to approximately $\$ 640-\$ 870$ in the last two decades of the century. Under RCP8.5, the effect of climate change first increases, but then decreases in size.

The spatial differences in the simulated effect of climate change on the production of the three staple foods are similar. The increment in or loss of production is larger in the central and southern areas of Taiwan. Overall, it is found in this study that the effects of climate change exhibit spatial and seasonal variations as in previous studies, for example, $[27,28]$. This result is consistent with the finding in previous studies, example, $[27,28]$. Additionally, the present study confirms one more possible source of variations in climate change impact, namely the variations across staple food commodities.

\section{Conclusions}

This study provides solid evidence and a significant complement to the existing body of knowledge through the investigation of the effect of climate conditions on both crop choice and subsequent production of the three most important staple foods. According to the estimates from the structural Ricardian model, the impacts of seasonal temperature variations are found to vary significantly across the staple food commodity chosen by the 
farm household. Among the three staple food crops, vegetables seem to be more sensitive to the seasonal variations in temperature. The effect of seasonal precipitation variations is also found to vary significantly across the staple food commodities. Our results indicate that increasing precipitation in the winter can significantly increase the production of fruits which is heavily concentrated in southern Taiwan, whereas rice production is the most sensitive to increasing precipitation in the spring.

Assessment of the impact of climate change under four RCP scenarios suggest the adverse effect of climate change on the production of rice and vegetables. Most of the effect of climate change, however, is positive for fruits. The simulated effect of climate change under different RCP scenarios also suggest significant spatial differences in the impact of climate change on the production of the three staple foods. Central and southern Taiwan are projected to experience more severe loss in rice and vegetables production than in other parts of the island.

Possible further exploration of the present work is two-fold. First, the use of adaptation strategies other than crop choice or the use of combined coping strategies may resolve the major limitation of this study. Second, some authors, for example, [53-55], indicated that climate change impact assessment should also take the frequency and severity of extreme climatic conditions into account. A possible extension of the present study is, therefore, to explicitly acknowledge the effect of extreme weather or disaster loss in assessing the impact of climate change.

Author Contributions: Conceptualization, Y.-H.L. and Y.-C.C.; methodology, Y.-H.L.; software, Y.H.L. and Y.-C.C.; validation, Y.-H.L.; formal analysis, Y.-H.L. and Y.-C.C.; investigation, Y.-H.L.; resources, Y.-H.L.; data curation, Y.-H.L. and Y.-C.C.; writing-original draft preparation, Y.-H.L. and Y.-C.C.; writing-review and editing, Y.-H.L.; visualization, Y.-H.L. and Y.-C.C.; supervision, Y.-H.L.; project administration, Y.-H.L.; funding acquisition, Y.-H.L. All authors have read and agreed to the published version of the manuscript.

Funding: Part of this research was funded by the Ministry of Technology and Science (MOST) in Taiwan, grant number: MOST-106-2410-H-002-018. The APC was funded by the MOST project undertaken by the author in the present.

Data Availability Statement: Publicly available datasets were analyzed in this study. The data can be found here: https: / / www.stat.gov.tw /lp.asp?ctNode=6592\&CtUnit=2393\&BaseDSD=7\&mp=4.

Conflicts of Interest: The authors declare no conflict of interest.

\section{Appendix A}

Table A1. Fruits and Vegetables.

\begin{tabular}{lllll}
\hline \multicolumn{2}{c}{ Fruits } & \multicolumn{3}{c}{ Vegetables } \\
\hline Apple & Persimmon & Amaranth & Ginger & Pea \\
Avocado & Pinang & Asparagus & Gracilaria & Pea seedlings \\
Banana & Pineapple & Asparagus bean & Green garlic & Potato \\
Carambola & Pitaya & Aubergine & Green onion & Pumpkin \\
Citrus & Plum & Bamboo shoot & Green soybean & Radish \\
Coconut & Plum flower & Big stem mustard & Gynura's Deux & Couleurs \\
Date palm & Pomelo & Bitter gourd & Kale & Sponge gourd \\
Grape & sweetsop & Burdock & Kohlrabi & Strawberry \\
Guava & Wax-jambos & Cabbage & Leaf mustard & Sweet potato \\
Litchi & & Calabash (gourd) & Leek & leaves \\
Loquat & & Carrot & Lettuce & Taro \\
Lungan & & Cauliflower & Lotus root & Tomato \\
\hline
\end{tabular}


Table A1. Cont.

\begin{tabular}{llll}
\hline \multicolumn{1}{c}{ Fruits } & \multicolumn{2}{c}{ Vegetables } \\
\hline Mango & Celery & Lotus seed & Water chestnut \\
Olive & Celery cabbage & Melon seeds & Water nut \\
Other fruit & Chillies & Muskmelon & Water spinach \\
Papaya & Coriander & Netted melon & Watermelon \\
Parami & Cucumber & Onion & Winter gourd \\
Passion fruit & Fern & Onion bulb & Yellow daylily \\
Peach & Garland & Oriental pickling & Other fruits \\
Pear & chrysanthemum & melon & \\
\hline
\end{tabular}

Table 2. Correlation coefficient of monthly temperature and precipitation.

\begin{tabular}{ccccccccccccc}
\hline Month & Jan & Feb & Mar & Apr & May & Jun & Jul & Aug & Sep & Oct & Nov & Dec \\
\hline Jan & 1 & 0.8698 & 0.9162 & 0.7584 & -0.6321 & 0.3298 & -0.155 & 0.0904 & 0.5398 & 0.9292 & 0.9111 & 0.9077 \\
Feb & 0.9846 & 1 & 0.9587 & 0.7775 & -0.6569 & 0.3892 & -0.097 & 0.1192 & 0.6651 & 0.8183 & 0.6767 & 0.9231 \\
Mar & 0.9039 & 0.9459 & 1 & 0.832 & -0.6543 & 0.5015 & -0.2304 & -0.0205 & 0.5345 & 0.8501 & 0.7491 & 0.9647 \\
Apr & 0.89 & 0.9202 & 0.9444 & 1 & -0.5808 & 0.5256 & -0.1507 & -0.2431 & 0.4705 & 0.6182 & 0.6002 & 0.8548 \\
May & 0.7752 & 0.8006 & 0.8093 & 0.9482 & 1 & 0.1046 & -0.1262 & -0.4045 & -0.4363 & -0.686 & -0.6786 & -0.5734 \\
Jun & 0.5929 & 0.5951 & 0.5663 & 0.761 & 0.9182 & 1 & -0.5089 & -0.5816 & 0.1048 & 0.1557 & 0.1359 & 0.5387 \\
Jul & 0.2225 & 0.2089 & 0.1489 & 0.3819 & 0.6366 & 0.8823 & 1 & 0.6763 & -0.045 & 0.0658 & -0.084 & -0.2741 \\
Aug & 0.4087 & 0.3981 & 0.3413 & 0.5685 & 0.7856 & 0.9595 & 0.9735 & 1 & 0.3478 & 0.3115 & 0.1819 & -0.134 \\
Sep & 0.6412 & 0.6581 & 0.6562 & 0.8511 & 0.9636 & 0.9501 & 0.7654 & 0.876 & 1 & 0.4863 & 0.374 & 0.5101 \\
Oct & 0.7966 & 0.8051 & 0.7917 & 0.9451 & 0.9804 & 0.8731 & 0.5801 & 0.7404 & 0.9567 & 1 & 0.9003 & 0.7971 \\
Nov & 0.8824 & 0.8935 & 0.8887 & 0.985 & 0.9643 & 0.8099 & 0.4645 & 0.6443 & 0.8995 & 0.9794 & 1 & 0.7333 \\
Dec & 0.9891 & 0.9901 & 0.9277 & 0.9162 & 0.7885 & 0.5701 & 0.173 & 0.3698 & 0.6486 & 0.812 & 0.8988 & 1 \\
\hline
\end{tabular}

Note: Upper triangle reports correlation coefficient of monthly precipitation; lower triangle reports that of monthly temperature. Different highlight colors represent correlations in different seasons-grey (winter), yellow (spring), blue (summer), green (fall).

\section{References}

1. Katz, R.W. Assessing the impact of climatic change on food production. Clim. Chang. 1977, 1, 85-96. [CrossRef]

2. White, J.W.; Hoogenboom, G.; Kimball, B.A.; Wall, G.W. Methodologies for simulating impacts of climate change on crop production. Field Crops Res. 2011, 124, 357-368. [CrossRef]

3. Ahmed, K.F.; Wang, G.; Yu, M.; Koo, J.; You, L. Potential impact of climate change on cereal crop yield in West Africa. Clim. Chang. 2015, 133, 321-334. [CrossRef]

4. Famien, A.M.; Janicot, S.; Ochou, A.D.; Vrac, M.; Defrance, D.; Sultan, B.; Noël, T. A bias-corrected CMIP5 dataset for Africa using the CDF-t method-A contribution to agricultural impact studies. Earth Syst. Dyn. 2018, 9, 313-338. [CrossRef]

5. Faye, B.; Webber, H.; Naab, J.B.; MacCarthy, D.S.; Adam, M.; Ewert, F.; Lamers, J.P.A.; Schleussner, C.F.; Ruane, A.; Gessner, U.; et al. Impacts of 1.5 versus $2.0^{\circ} \mathrm{C}$ on cereal yields in the West African Sudan Savanna. Environ. Res. Lett. 2018, $13,034014$. [CrossRef]

6. Mabhaudhi, T.; Nhamo, L.; Mpandeli, S.; Naidoo, D.; Nhemachena, C.; Sobratee, N.; Slotow, R.; Liphadzi, S.; Modi, A.T. The water-energy-food nexus as a tool to transform rural livelihoods and wellbeing in southern Africa. Int. J. Environ. Res. Public Health 2019, 16, 2970. [CrossRef]

7. Sultan, B.; Defrance, D.; Iizumi, T. Evidence of crop production losses in West Africa due to historical global warming in two crop models. Sci. Rep. 2019, 9, 12834. [CrossRef]

8. Sultan, B.; Parkes, B.; Gaetani, M. Direct and indirect effects of CO2 increase on crop yield in West Africa. Int. J. Clim. 2019, 39, 2400-2411. [CrossRef]

9. Defrance, D.; Sultan, B.; Castets, M.; Famien, A.M.; Baron, C. Impact of Climate Change in West Africa on Cereal Production Per Capita in 2050. Sustainability 2020, 12, 7585. [CrossRef]

10. Reynolds, M.; Ortiz, R. Adapting crops to climate change: A summary. In Climate Change and Crop Production; Reynolds, M.P., Ed.; CAB International: Wallingford, UK, 2010; pp. 1-8.

11. Davis, C.L.; Vincent, K. Climate Risk and Vulnerability: A Handbook for Southern Africa, 2nd ed.; CSIR: Pretoria, South Africa, 2017; p. 202.

12. Nhamo, L.; Matchaya, G.; Mabhaudhi, T.; Nhlengethwa, S.; Nhemachena, C.; Mpandeli, S. Cereal production trends under climate change: Impacts and adaptation strategies in Southern Africa. Agriculture 2019, 9, 30. [CrossRef] 
13. Mendelsohn, R.; Dinar, A.; Williams, L. The distributional impact of climate change on rich and poor countries. Environ. Dev. Econ. 2006, 11, 159-178. [CrossRef]

14. Liu, J.; Folberth, C.; Yang, H.; Röckström, J.; Abbaspour, K.; Zehnder, A.J.B. A global and spatially explicit assessment of climate change impacts on crop production and consumptive water use. PLoS ONE 2013, 8, e57750. [CrossRef]

15. Mendelsohn, R.; Massetti, E. The use of cross-sectional analysis to measure climate impacts on agriculture: Theory and evidence. Rev. Environ. Econ. Policy 2017, 11, 280-298. [CrossRef]

16. Deressa, T.T.; Hassan, R.M. Economic impact of climate change on crop production in Ethiopia: Evidence from cross-section measures. J. Afr. Econ. 2009, 18, 529-554. [CrossRef]

17. Wang, J.; Mendelsohn, R.; Dinar, A.; Huang, J.; Rozelle, S.; Zhang, L. The impact of climate change on China's agriculture. Agric. Econ. 2009, 40, 323-337. [CrossRef]

18. Masud, M.M.; Rahman, M.S.; Al-Amin, A.Q.; Kari, F.; Filho, W.L. Impact of climate change: An empirical investigation of Malaysian rice production. Mitig. Adapt. Strat. Glob. Chang. 2012, 19, 431-444. [CrossRef]

19. Ahmad, A.; Ashfaq, M.; Rasul, G.; Wajid, S.A.; Khaliq, T.; Rasul, F.; Saeed, U.; ur Rahman, M.H.; Hussain, J.; Baig, I.A.; et al. Cereal production in the presence of climate change in China. In Handbook of Climate Change and Agroecosystems; Rosenzweig, C., Hillel, D., Eds.; Imperial College Press: London, UK, 2015; pp. 219-258.

20. Bawayelaazaa Nyuor, A.; Donkor, E.; Aidoo, R.; Saaka Buah, S.; Naab, J.B.; Nutsugah, S.K.; Bayala, J.; Zougmoré, R. Economic impacts of climate change on cereal production: Implications for sustainable agriculture in Northern Ghana. Sustainability 2016, 8 , 724. [CrossRef]

21. Arshad, M.; Amjath-Babu, T.S.; Krupnik, T.J.; Aravindakshan, S.; Abbas, A.; Kächele, H.; Müller, K. Climate variability and yield risk in South Asia's rice-wheat systems: Emerging evidence from Pakistan. Paddy Water Environ. 2017, 15, 249-261. [CrossRef]

22. Mendelsohn, R.; Wang, J. The impact of climate on farm inputs in developing country agriculture. Atmosfera 2017, 30, 77-86. [CrossRef]

23. Fahad, S.; Wang, J. Farmers' risk perception, vulnerability, and adaptation to climate change in rural Pakistan. Land Use Policy 2018, 79, 301-309. [CrossRef]

24. Gao, J.; Mills, B.F. Weather shocks, coping strategies, and consumption dynamics in rural Ethiopia. World Dev. 2018, 101, 268-283. [CrossRef]

25. Nahar, A.; Luckstead, J.; Wailes, E.J.; Alam, M.J. An assessment of the potential impact of climate change on rice farmers and markets in Bangladesh. Clim. Change 2018, 150, 289-304. [CrossRef]

26. Chuang, Y. Climate variability, rainfall shocks, and farmers' income diversification in India. Econ. Lett. 2019, 174, 55-61. [CrossRef]

27. Hossain, M.S.; Arshad, M.; Qian, L.; Zhao, M.; Mehmood, Y.; Kächele, H. Economic impact of climate change on crop farming in Bangladesh: An application of Ricardian method. Ecol. Econ 2019, 164, 106354. [CrossRef]

28. Hossain, M.S.; Qian, L.; Arshad, M.; Shahid, S.; Fahad, S.; Akhter, J. Climate change and crop farming in Bangladesh: An analysis of economic impacts. Int. J. Clim. Chang. Strateg. Manag. 2019, 11, 424-440. [CrossRef]

29. Directorate General of Budget, Accounting and Statistics. 2015 Agriculture, Forestry, Fishery and Animal Husbandry Census Report; DGBAS: Taipei, Taiwan, 2017.

30. Shogenji, S.-I. Current position and future direction of agriculture in northeast Asia. In Food Security and Industrial Clustering in Northeast Asia; Kiminami, L., Nakamura, T., Eds.; Springer: Tokyo, Japan, 2016; pp. 33-45.

31. Geography of Taiwan, The Climate of Taiwan. Available online: http://twgeog.ntnugeog.org/en/climatology/ (accessed on 8 November 2020).

32. Mendelsohn, R.; Nordhaus, W.D.; Shaw, D. The impact of global warming on agriculture: A Ricardian analysis. Am. Econ. Rev. 1994, 84, 753-771.

33. Kurukulasuriya, P.; Mendelsohn, R. Modeling Endogenous Irrigation: The Impact of Climate Change on Farmers in Africa; Policy Research Working Paper; No. 4278; World Bank: Washington, DC, USA, 2007.

34. Kurukulasuriya, P.; Mendelsohn, R. Crop switching as a strategy for adapting to climate change. Afr. J. Agric. Resour. Econ. 2008, 2, 105-125.

35. Seo, S.N.; Mendelsohn, R.; Munasinghe, M. Climate change and agriculture in SriLanka: A Ricardian valuation. Environ. Dev. Econ. 2005, 10, 581-596. [CrossRef]

36. Seo, S.N.; Mendelsohn, R. A Ricardian Analysis of the Impact of Climate Change on Latin American Farms; Policy Research Working Paper; No. 4163; World Bank: Washington, DC, USA, 2007.

37. Seo, N.; Mendelsohn, R. Measuring impacts and adaptation to climate change: A structural Ricardian model of African livestock management. Agric. Econ. 2008, 38, 151-165. [CrossRef]

38. Kurukulasuriya, P.; Kala, N.; Mendelsohn, R. Adaptation and climate change impacts: A structural Ricardian model of irrigation and farm income in Africa. Clim. Chang. Econ. 2011, 2, 149-174. [CrossRef]

39. Chatzopoulos, T.; Lippert, C. Adaptation and climate change impacts: A structural Ricardian analysis of farm types in Germany. J. Agric. Econ. 2015, 66, 537-554. [CrossRef]

40. Abidoye, B.O.; Kurukulasuriya, P.; Reed, B.; Mendelsohn, R. Structural Ricardian analysis of south-east Asian agriculture. Clim. Chang. Econ. 2017, 8, 1740005. [CrossRef]

41. Etwire, P.M.; Fielding, D.; Kahui, V. Climate change, crop selection and agricultural revenue in Ghana: A structural Ricardian analysis. J. Agric. Econ. 2019, 70, 488-506. [CrossRef] 
42. Huong, N.T.L.; Bo, Y.S.; Fahad, S. Economic impact of climate change on agriculture using Ricardian approach: A case of northwest Vietnam. J. Saudi Soc. Agric. Sci. 2019, 18, 449-457. [CrossRef]

43. National Science \& Technology Center for Disaster Reduction. The Past and Future of Taiwan's Climate; Research Center for Environmental Changes Academic Sinica: Taipei, Taiwan, 2018.

44. National Science \& Technology Center for Disaster Reduction. Climate Change in Taiwan: Scientific Report 2017. Physical Phenomena and Mechanisms, General Summary; Research Center for Environmental Changes Academic Sinica: Taipei, Taiwan, 2018.

45. Central Weather Bureau, Climatic Characteristics of Seasonal Rainfall in Taiwan. Available online: https://www.cwb.gov.tw/ Data/service/hottopic/14277057430.pdf (accessed on 17 October 2020).

46. Dubin, J.; McFadden, D. An econometric analysis of residential electric appliance holdings and consumption. Econometrica 1984, 52, 345-362. [CrossRef]

47. McFadden, D. Conditional logit analysis of qualitative choice behavior. In Frontiers in Econometrics; Zarembka, P., Ed.; Academic Press: New York, NY, USA, 1974; pp. 105-142.

48. Maddala, G.S. Limited-Dependent and Qualitative Variables in Econometrics; Cambridge University Press: New York, NY, USA, 1983.

49. Moore, M.; Negri, D. A multiple production model of irrigated agriculture applied to water allocation policy of the bureau of reclamation. J. Agric. Resour. Econ. 1992, 17, $29-43$.

50. Wang, J.; Mendelsohn, R.; Dinar, A.; Huang, J. How Chinese farmers change crop choice to adapt to climate change. Clim. Chang. Econ. 2010, 1, 167-185. [CrossRef]

51. Directorate General of Budget, Accounting and Statistics. Farm Household Frequency Distribution of Major Commodities in the 2015 Agriculture, Forestry, Fishery and Animal Husbandry Census Survey; DGBAS: Taipei, Taiwan, 2017.

52. Taiwan Climate Change Projection Information and Adaptation Knowledge Platform. Available online: https:/ / tccip.ncdr.nat. gov.tw /index_eng.aspx (accessed on 17 October 2020).

53. Rosenzweig, C.; Iglesius, A.; Yang, X.B.; Epstein, P.R.; Chivian, E. Climate change and extreme weather events-Implications for food production, plant diseases, and pests. Glob. Chang. Hum. Health 2001, 2, 90-104. [CrossRef]

54. Monirul, M.M.Q. Climate change and extreme weather events: Can developing countries adapt? Clim. Policy 2003, 3, 233-248.

55. Wang, S.L.; Ball, E.; Nehring, R.; Williams, R.; Chau, T. Impacts of Climate Change and Extreme Weather on U.S. Agricultural Productivity: Evidence and Projection; NBER Working Paper; No. 23533; National Bureau of Economic Research: Cambridge, UK, 2017. 